\title{
Perception of Present and Vision of Future of Gifted Students
}

\author{
Docent Ljiljana Krneta \\ Faculty of Political Sciences, University of Banja Luka, Bosnia and Herzegovina
}

Copyright $(2016$ by authors, all rights reserved. Authors agree that this article remains permanently open access under the terms of the Creative Commons Attribution License 4.0 International License

\begin{abstract}
Giftedness and talent are the focus of many professional and scientific debates. Starting from the phenomenological interpretation that emphasizes the perception of self and reflects the subjective experience of the present and the future, the author presents the attitude of the gifted and other students towards the psychological nature of self-awareness. This includes the emotions - values components of personality and relation towards self-awareness. The empirical and non-experimental research was conducted on a sample of 688 high school students (grammar, technical, art schools). The sample included students from various places, aged 15 to 18 years. The survey was conducted in order to examine the perception of the present and the vision of future of the gifted and other students, as determinants of self-awareness. The study results showed that there is a statistically significant difference in the perception of the present, between the gifted and other students. The gifted students appear to have gloomier perception of present in relation to other students. In the perception of the vision of future between the gifted and other students, there were no statistically significant differences in their views of future. The results point to a great need for more empirical studies on the topic of giftedness in the region and more complex review of personality of giftedness using a holistic approach. At a time of global changes, which encompass all segments of society, inevitably raises the question of quality of education for the gifted and other students. These topics are very complex and require a serious pluralistic approach to different paradigms and theories, as well as empirical validation. Therefore, the issue of quality of education of gifted is an imperative and a challenge of the modern humanistic approach in education.
\end{abstract}

Keywords Gifted, Perception, School Performance, Self-awareness

\section{Introduction}

Data on the research of giftedness show that during the twentieth century there were over 1554 publications on the topic Djuric[2] 1987, which indicates the importance and interest of the scientific and professional public for the topic of giftedness and talent. Although the first interest for the topic of gifted occurred even in ancient civilizations of China, India, Greece. In the XX and XXI century giftedness is systematically and scientifically researched and studied. The development of a society may be evaluated by the degree of identification, development and status of gifted and it becomes a civilizational challenge. Most of the research is dedicated to the study of cognitive aspects of the gifted Gojkov [4], Djordjevic-Djordjevic [3], and Andrilovic-Cudina [1]. But the contemporary discourse of giftedness pays special attention to the emotional and social aspects of personality of gifted individuals. Although there are not enough empirical research on this segment of giftedness in the region, Havelka [5], Roth-Havelka [ 16], Kvascev [13], Kvascev-Radovanovic [14], Krneta 2002[7], Krneta D-Krneta Lj [8:113-147] and Krneta Lj[10,11], Krneta-Simunic [12:200-215] the issues of quality of education of gifted are increasingly the subject of discussion in scientific circles. In the context of the commitment to quality education, a wide-range issue of our research is the analysis of factors affecting the performance of high school students, while a narrow-range issue of the research is related to what we used for examining the performance of gifted high school students, i.e. self-awareness. We are particularly interested in the analysis of relation between self-awareness and school performance of gifted students. Known are many factors affecting the school performance of students. However, analysts do agree that those factors can be classified into three broad categories: a) factors operating in a social environment, b) factors operating from the scope of teacher's work, and c) factors regarding the characteristics of students. Roth, N.[6] points out the complexity of the influence of socio-psychological factors on attitudes and opinions, emphasizing their significant role in explaining the behavior, because attitudes and values are the result of socialization. Analyzing the performance of students, we shall start from the status of a student in a social environment being quite dependent on a grade he/she got and success in 
school he/she achieved. School grades may be an important factor of further promotion and a factor of personality perception, greatly affecting the entire personality development ${ }^{1}$. School performance of gifted students expressed in numbers (from 1 to 5) is an evaluation of the extent in which a student mastered particular subject (i.e. acquired some knowledge) during a certain period of educational process. In this paper, we decided to perceive the distribution of school success through the distribution of student's success in the previous grade, as an indicator of real effectiveness of gifted and other students during their regular schooling. In that context, there has been set a specific hypothesis that no significant differences in school success between gifted and other students may be expected. Self-awareness - in the analysis of subjective experience of both gifted and other students there were perceived two important aspects: the perception of present and the vision of future. Both aspects carry within themselves that emotion - value character, as a referential framework for adjusting the behavior of an individual, in everyday activities and planning of some relevant activities in the near and far future. In Psychology, the terms of perception of present and vision of future are regarded as important within the identity analysis of an individual (identity, self-consciousness, self, self-system, self-image, self-concept); so it is important to emphasize that they are an integral part of self-image or self-consciousness. Therefore, we shall assume that both perception of present and vision of future are phenomena, relevant for the development of gifted students during their schooling as well as in the self-actualization process, later on. They are particularly important in the relation of an individual toward tasks that person set himself/herself as some relevant goals and tasks to which he/she strives in his/her life. In that view, there has been set a specific hypothesis that no significant differences in the perception of present and the vision of future between both gifted and other students may be expected. However, we shall assume that all persons set some goals to themselves to which they strive in their lives and according to which they adjust their activities and behavior in the social environment, so no differences among young high school students, nor gifted and other students may be expected.

\section{Research Concept}

A great number of researches conducted in the world and the region is dedicated to researching of the cognitive aspects of giftedness. More and more often, the performance of gifted high school students is becoming the subject of discussions. In the tradition of our educational system, some systematic support to the gifted has not been developed yet,

\footnotetext{
1 In 2000, Krneta $\mathrm{Lj}$. presented the results of psycho-social factors influencing the school success of students in the monograph "Factors of School Performance".
}

although the needs of society development impose that as an imperative of development, constantly. The remains of "old awareness" and resistance to new ideas and different perception of giftedness are still present. Not only practitioners but analysts of educational system as well do agree unequivocally that the success in school of both gifted and other students is, more or less, under the influence of multiple factors (the characteristics of a student, the organization of educational process, the grading system, etc.). Among factors affecting the school success of gifted, those factors arising from characteristics of a student are most researched ones. In the beginning the success in school had been explained due to dominant influence of cognitive aspects of personality, but later on researches showed that the school success of gifted and other students was influenced mostly by cognitive, conative and affective components of personality. In this paper, we shall show a part of results, related to the perception of the relation of self-awareness and school performance of gifted students.

This research has transversal character i.e. it is based on inductive collecting of data in a particular time period and how its results may have some practical implications: a) $A$ scientific goal of the research is to determine similarities and differences in the perception of school performance of gifted students. Also, a special attention is paid to the analysis of the relation between self-awareness and school performance of gifted students, that is, to the search for an answer on question whether self-awareness (and other socio-experiential features) may be determinant for the perception of school performance of gifted students. b) $A$ practical goal: the research of the relations of self-awareness and school performance of gifted students, lies in the fact the acquired data of research do not only give an objective picture of those gifted in the society and school but suggest a possible course of actions of educational policy makers and changes of unfavourable aspects of the position of gifted in the school and society. Within such a research concept, the general hypothesis shall read: statistically significant differences in school performance of gifted students, related to self-awareness, may be expected. We shall be particularly interested in two aspects of relations:

1. We assume there is a statistically significant difference in school performance of gifted with regard to self-awareness, i.e. the differences in the perception of the present.

2. We assume there is a statistically significant difference in school performance between gifted and other students with regard to self-awareness, i.e. the differences in the vision of the future.

\section{Research Method}

The research has been conducted as a transversal research, meaning it gives a snapshot of examined characteristics of respondents in a particular time period. For these purposes, we used the survey method, as a basic method, in 
combination with the theory analysis method and comparison method.

The SAMPLE of this research includes 688 high school students the Republic of Srpska, Bosnia and Herzegovina being divided into two subsamples: a) a sample of gifted, and b) a sample of other students. All students of art schools and students of other high schools, who show a high degree of giftedness in some field or who participated in some competitions at regional, federal of higher levels are classified into a subsample of gifted $(\mathrm{N}=216)$. Another subsample includes students attending other vocational and technical schools and grammar schools $(\mathrm{N}=472)$, who did not declare on their specific abilities in any particular field nor participation in any competition.

Table 1. The structure of samples with regard to features

\begin{tabular}{|c|c|c|}
\hline Type of school & $\mathrm{N}$ & $\%$ \\
\hline - Technical & 310 & 45.05814 \\
\hline - Grammar & 162 & 23.54651 \\
\hline -Art & 216 & 31.39535 \\
\hline
\end{tabular}

\begin{tabular}{|c|c|c|}
\hline Age & $\mathrm{N}$ & $\%$ \\
\hline 15 & 40 & 5.81395 \\
\hline 16 & 102 & 14.82558 \\
\hline 17 & 292 & 42.44186 \\
\hline 18 & 254 & 36.91860 \\
\hline
\end{tabular}

\begin{tabular}{|c|c|c|}
\hline Sex & N & $\%$ \\
\hline - no answer & 6 & .87209 \\
\hline - female & 346 & 50.29070 \\
\hline - male & 336 & 48.83721 \\
\hline
\end{tabular}

\begin{tabular}{|c|c|c|}
\hline Class & N & $\%$ \\
\hline First & 110 & 15.98837 \\
\hline Second & 80 & 11.62791 \\
\hline Third & 498 & 72.38372 \\
\hline
\end{tabular}

\begin{tabular}{|c|c|c|}
\hline Success at the end of school & N & $\%$ \\
\hline - good & 126 & 18.31395 \\
\hline - very good & 324 & 47.09302 \\
\hline - excellent & 238 & 34.59302 \\
\hline
\end{tabular}

\begin{tabular}{|c|c|c|}
\hline Success at midterm & $\mathrm{N}$ & $\%$ \\
\hline - insufficient & 130 & 18.89535 \\
\hline - sufficient & 12 & 1.74419 \\
\hline - good & 114 & 16.56977 \\
\hline - very good & 294 & 42.73256 \\
\hline - excellent & 138 & 20.05814 \\
\hline
\end{tabular}

\begin{tabular}{|c|c|c|}
\hline Success in the previous grade & N & $\%$ \\
\hline - insufficient & 2 & .29070 \\
\hline - sufficient & 16 & 2.32558 \\
\hline - good & 236 & 34.30233 \\
\hline - very good & 252 & 36.62791 \\
\hline - excellent & 182 & 26.45349 \\
\hline
\end{tabular}

Based on the insight into a sample structured in such a way, it may be concluded that the sample is multistage, appropriate with the elements of random selection, which shall be regarded as adequate and representative for the purposes of this type of research. Therefore, it follows that the gained results, as well as conclusions made with regard to them, may be reliable, and the concluded generalizations regarded as scientifically objective.

\section{Instruments}

In order to collect data, we used a QUESTIONNAIRE for students about their relevant features and a SCALE for testing self-awareness, which includes a scale of the perception of present and a scale of the vision of future Havelka [6]. The data obtained in the research, [6] can be used for comparison with data from similar researches. In this context, we used the scale of life understanding, which highlights the significant aspect of self-awareness. The scale is taken from the research conducted in 2001 by Gorjana Litvanovic [15], "Perceived changes, time orientation and personal satisfaction during a life time in Yugoslavia and USA". The scale contains 15 questions, related to the perception of the present and 8 questions related to the perception of the future. The questions are constructed in such a manner that responses can be used in understanding the thoughts and views of respondents about the present, for example - "These days I am very happy." The respondents answered on continuum of "completely true" to "not true at all". The vision of the future was examined in a similar manner. So to the question "Do you look forward to the arrival of the future?", the respondents also answered on the continuum from "very much" to "none". Internal consistency of the scale is satisfactory, taking into account the value of Cronbach's alpha coefficient in our research is A) 0.92 (a scale of the perception of present) and B) 0.84 (a scale of the vision of future).

The obtained results of individual evaluation of respondents are summarized for all items in order to determine the total individual score which shall show the relation of respondents toward the present and their vision of the future. Interpretation of results shall be expressed on the continuum which may be optimistic, ambivalent and pessimistic. 


\section{Relations between School Performance of Gifted and Perception of the Present}

Known are different theoretical approaches to the phenomenon of talent. Contemporary didactics of gifted and the first researches on new and insufficiently known fields with the goal of creating new didactics in working with gifted of all ages brought [4]. In scientific papers Gojkov [4] writes about complexity of postmodern paradigms and the phenomenon of giftedness, creativity and talent. The important issue of contemporary school and the impact of globalization is the question of performance of gifted and other students. Therefore, this issue, at the time of global challenges, receives more attention Krneta, $[10,11])$, and the focus is on the psychological nature of giftedness within the contemporary environmental conditions (globalization).

Public interest for school success of students does not only emerge from the requirement to satisfy indirect educational needs but represents an indirect indicator of the relation of the level of society development and educational system development because the contemporary society needs more modern and efficient education. Therefore, the indicators of distribution of school success can show practically the successfulness of school system and its efficiency in the society, for an individual and for the society. Bearing in mind the fact the students' success is affected by different factors, in this paper we shall show the distribution of school success of students for the previous class, as indicators of real efficiency of students during their regular schooling.

Table 2. Giftedness and success in the previous grade

\begin{tabular}{|c|c|c|c|c|c|c|}
\hline & \multicolumn{5}{|c|}{ Success in the previous grade } & \multirow{2}{*}{$\sum$} \\
\cline { 2 - 6 } & insufficient & sufficient & good & $\begin{array}{c}\text { very } \\
\text { good }\end{array}$ & excellent & \\
\hline \multirow{3}{*}{ Others } & 2 & 6 & 188 & 158 & 118 & \multirow{2}{*}{472} \\
\cline { 2 - 6 } & .42 & 1.27 & 39.83 & 33.47 & 25.00 & \\
\hline \multirow{3}{*}{ Gifted } & 0 & 10 & 48 & 94 & 64 & \multirow{2}{*}{216} \\
\cline { 2 - 6 } Total & 0.00 & 4.63 & 22.22 & 43.52 & 29.63 & \\
\cline { 2 - 6 } & 2 & 16 & 236 & 252 & 182 & \multirow{2}{*}{688} \\
\hline
\end{tabular}

Pearson Chi-square: $26.7786, \mathrm{df}=4, \mathrm{p}=.000022$

The distribution of school success of gifted and other students for the whole sample is given in Table 2. The analysis of results given in Table 2 suggests undoubtedly that the school success of surveyed students is distributed toward above-average (very good and excellent) grades (63.08\%), but quite little toward below-average grades: sufficient $(2.33 \%)$ and insufficient $(0.29 \%)$. To be precise, the distribution of school success of gifted and other students for the whole sample (gifted and other students) shall read as follows: 2 or $0.29 \%$ of students who repeat the class, 16 or $2.33 \%$ of students with a grade sufficient, 236 or $35.30 \%$ of students with a grade good, 252 or $36.63 \%$ of students with a grade very good, and 182 or $26.45 \%$ of students with a grade excellent. Furthermore, an insight into the distribution of success of gifted and other students indicates some significant differences. There are fewer differences in the percentage of students with a grade sufficient $(1.27 \%)$, and many in the percentage of students with a grade good (39.83\% versus $22.22 \%$ ). A grade very good was obtained by $43.51 \%$ of gifted and $33.47 \%$ of other students. Based on such a distribution of results of school success of both gifted and other students, it is evident the gifted students had significantly higher school success, because many of them had completed a class with grades very good and excellent rather than with grades good and sufficient. Those differences are statistically significant as well, because the obtained Chi-square test, Pearson Chi-square: 26.7786, with 4 degrees of freedom, is important at the level of 0.01 $(\mathrm{p}=.000022)$.

Self-awareness is quite important in interpreting the performance of gifted and other students. It was perceived through two aspects: 1 . -the perception of the present, and 2. -the vision of the future, important for the behavior of an individual and in everyday activities and planning of relevant activities for both near and far future.

Table 3. Distribution of the results of the perception of present - whole sample

\begin{tabular}{|c|c|c|}
\hline & $\mathrm{N}$ & $\%$ \\
\hline - Very negative & 0 & 0.00 \\
\hline - Mainly negative & 20 & 2.91 \\
\hline - Unsure & 212 & 30.81 \\
\hline - Mainly positive & 384 & 55.81 \\
\hline - Very positive & 72 & 10.46 \\
\hline
\end{tabular}

The obtained results show that the surveyed students perceive certain aspects of their own life in the present with different intensity and direction, exhibit varying degrees of acceptance or rejection of certain items. It is evident that the positive formulations of the present are positioned around mid-continuum, and the negative formulations of the present are distributed to ends of the continuum. Illustrative response is a statement: "These days I find that my life is just as it should be," has a value of 3.57 , which shows that one in two respondents, or $54.64 \%$ of the students gave a positive answer on this item. 20. 34\% gave "very positive" and $14.52 \%$ negative answer, of which $2.90 \%$ gave a "very negative" answer, and $11.62 \%$ of moderate-intensity "Mostly not true." It is evident that none of respondents perceived the present with "very negative". I n this context, the results of perception of present among students show that, despite the difficult socio-economic situation in which young people live, they expressed more positive than negative or neutral attitudes toward the present, supporting our standpoint that all persons set goals to which they strive in their lives and according to which they undertake actions in a real social environment.

One of the important issues in this study refers to the 
examination of the similarities and differences in perception of the present between gifted and other students. In this regard, set is a special hypothesis "that the differences in perception of present between gifted and other students can be expected".

Table 4. Perception of present of gifted and other students

\begin{tabular}{|c|c|c|c|c|c|}
\hline \multirow{3}{*}{ Students } & \multicolumn{4}{|c|}{ Attitude towards the present } & \multirow{2}{*}{$\sum$} \\
\cline { 2 - 5 } & $\begin{array}{c}\text { Mainly } \\
\text { negative }\end{array}$ & Not sure & $\begin{array}{c}\text { Mainly } \\
\text { positive }\end{array}$ & $\begin{array}{c}\text { Very } \\
\text { positive }\end{array}$ & \\
\hline \multirow{2}{*}{ Gifted } & 8 & 80 & 102 & 26 & \multirow{2}{*}{216} \\
\cline { 2 - 5 } & 3.70 & 37.04 & 47.22 & 12.04 & \\
\hline \multirow{2}{*}{$\begin{array}{c}\text { Other } \\
\text { students }\end{array}$} & 12 & 132 & 282 & 46 & \multirow{2}{*}{472} \\
\cline { 2 - 5 } & 2.54 & 27.97 & 59.75 & 9.75 & \\
\hline Total & 20 & 212 & 384 & 72 & \multirow{2}{*}{688} \\
\hline & 2.91 & 30.81 & 55.81 & 10.47 & \\
\hline
\end{tabular}

Pearson Chi-square: $9.55196, \mathrm{df}=3, \mathrm{p}=.022798$

The results indicate that there are statistically significant differences in perception of present between gifted and other students, (Chi-square $=9,55196$, with three degrees of freedom results in significant statistically at the level of 0.05 $(p=.022798))$. The distribution of results of present perception show that there have been established significant differences between gifted and other students in their perception of the present, so the risk of accepting the hypothesis is at the level of 5\%. The analysis shows that with gifted students prevail mainly positive attitudes toward the present, $47.22 \%$, then "not sure" attitude, as perceived by $37.04 \%$, while far fewer of those with a very positive attitude $12.04 \%$ and a mainly negative $-3.70 \%$. On the other side, non-gifted students were a lot more with moderately positive attitude, 59.75\% (than the gifted, 47.22\%) and less hesitant attitude of $27.97 \%$ (gifted $37.04 \%$ ), moderate negative
$2.54 \%(3.70 \%$ for the gifted) and those with a positive attitude $9.75 \%$ (under $12.04 \%$ for gifted). It seems that gifted have more of a negative attitude toward the present, and this in turn leads to, maybe, a more pessimistic perception of the present. Also, it shall lead to accepting the hypothesis "that differences in the perception of present between gifted and other students may be expected".

\section{Vision of the Future}

To look into the vision of the future of gifted and other students, we used a scale to test students' thoughts and views of the future, based on which is determined $b$ general attitude towards future. The scale which was used is a Likert's scale and contains 8 items that relate to students' thoughts and views on various aspects of the future. The items are worded as positive and negative items, for example. "Do you look forward to the arrival of the future" and the answers are grouped on five-point scale from "very high" to "not at all".

Analysis of the results shows that the vision of the future is, in a more pronounced degree stated in terms of accepting the items that point to the thoughts about the future and the hope that the future will be good, and less on items related to the importance of the future or looking forward to the futures' coming. This can be seen from results, showing the most acceptable items such as, "Do you think about the future?"(3.71); "Is future more important than the past?" (3.67); "How much you believe that your future will be good?" (3.64) and "How much wellbeing do you expect from your future" (3.63). The least acceptable items include "Is the future more important than the present" (-2.87) and "Are you looking forward to your future?" (3.19). The results of the vision of future of surveyed students distributed in such a manner give a precise picture of students toward their future.

Table 5. Distribution of the results for the vision of future - whole sample

\begin{tabular}{|c|c|c|c|c|c|c|c|}
\hline 35. What are your thoughts and views of the future? & $\mathrm{AC}$ & Very much & Much & Moderately & Little & $\begin{array}{l}\text { Very } \\
\text { little }\end{array}$ & $\begin{array}{c}\text { No } \\
\text { answer }\end{array}$ \\
\hline - Do you think about the future? & 3.71 & $\begin{array}{c}252 \\
36.62\end{array}$ & $\begin{array}{c}134 \\
19.47\end{array}$ & $\begin{array}{c}194 \\
28.19\end{array}$ & $\begin{array}{c}70 \\
10.17\end{array}$ & $\begin{array}{c}30 \\
4.36\end{array}$ & $\begin{array}{c}8 \\
1.16\end{array}$ \\
\hline - Is future more important to you than the past? & 3.67 & $\begin{array}{c}246 \\
35.75\end{array}$ & $\begin{array}{c}160 \\
23.25\end{array}$ & $\begin{array}{c}166 \\
24.12\end{array}$ & $\begin{array}{c}50 \\
7.26\end{array}$ & $\begin{array}{c}62 \\
9.01\end{array}$ & $\begin{array}{l}4 \\
.58\end{array}$ \\
\hline $\begin{array}{l}\text { - How much do you believe that your future will } \\
\text { be good? }\end{array}$ & 3.64 & $\begin{array}{c}120 \\
17.44 \\
\end{array}$ & $\begin{array}{c}248 \\
36.04 \\
\end{array}$ & $\begin{array}{c}278 \\
40.40 \\
\end{array}$ & $\begin{array}{c}36 \\
5.23 \\
\end{array}$ & $\begin{array}{c}6 \\
.87 \\
\end{array}$ & $\begin{array}{c}0 \\
.00 \\
\end{array}$ \\
\hline $\begin{array}{l}\text { How much wellbeing do you expect from your } \\
\text { future? }\end{array}$ & 3.63 & $\begin{array}{c}96 \\
13.95 \\
\end{array}$ & $\begin{array}{c}294 \\
42.73 \\
\end{array}$ & $\begin{array}{c}250 \\
36.33 \\
\end{array}$ & $\begin{array}{c}42 \\
6.10 \\
\end{array}$ & $\begin{array}{c}6 \\
.87 \\
\end{array}$ & $\begin{array}{c}0 \\
.00 \\
\end{array}$ \\
\hline Do you dread the future? & 3.43 & $\begin{array}{c}58 \\
8.43 \\
\end{array}$ & $\begin{array}{c}50 \\
7.26 \\
\end{array}$ & $\begin{array}{c}236 \\
34.30 \\
\end{array}$ & $\begin{array}{c}216 \\
31.39 \\
\end{array}$ & $\begin{array}{c}126 \\
18.31\end{array}$ & $\begin{array}{l}2 \\
.29\end{array}$ \\
\hline $\begin{array}{l}\text { Are you worried when thinking about your } \\
\text { future? }\end{array}$ & 3.29 & $\begin{array}{c}72 \\
10.46 \\
\end{array}$ & $\begin{array}{c}74 \\
10.75 \\
\end{array}$ & $\begin{array}{c}228 \\
33.13 \\
\end{array}$ & $\begin{array}{c}184 \\
26.74\end{array}$ & $\begin{array}{c}126 \\
18.31\end{array}$ & $\begin{array}{l}4 \\
.58 \\
\end{array}$ \\
\hline - Are you looking forward to your future? & 3.19 & $\begin{array}{c}122 \\
17.73 \\
\end{array}$ & $\begin{array}{c}156 \\
22.67\end{array}$ & $\begin{array}{c}228 \\
33.13\end{array}$ & $\begin{array}{c}102 \\
14.82\end{array}$ & $\begin{array}{c}72 \\
10.46\end{array}$ & $\begin{array}{c}8 \\
1.16\end{array}$ \\
\hline $\begin{array}{l}\text { Is the future more important than the present, } \\
\text { in your opinion? }\end{array}$ & 2.87 & $\begin{array}{c}94 \\
13.66 \\
\end{array}$ & $\begin{array}{c}120 \\
17.44 \\
\end{array}$ & $\begin{array}{c}230 \\
33.43 \\
\end{array}$ & $\begin{array}{c}94 \\
13.66 \\
\end{array}$ & $\begin{array}{c}150 \\
21.80 \\
\end{array}$ & $\begin{array}{c}0 \\
.00 \\
\end{array}$ \\
\hline
\end{tabular}




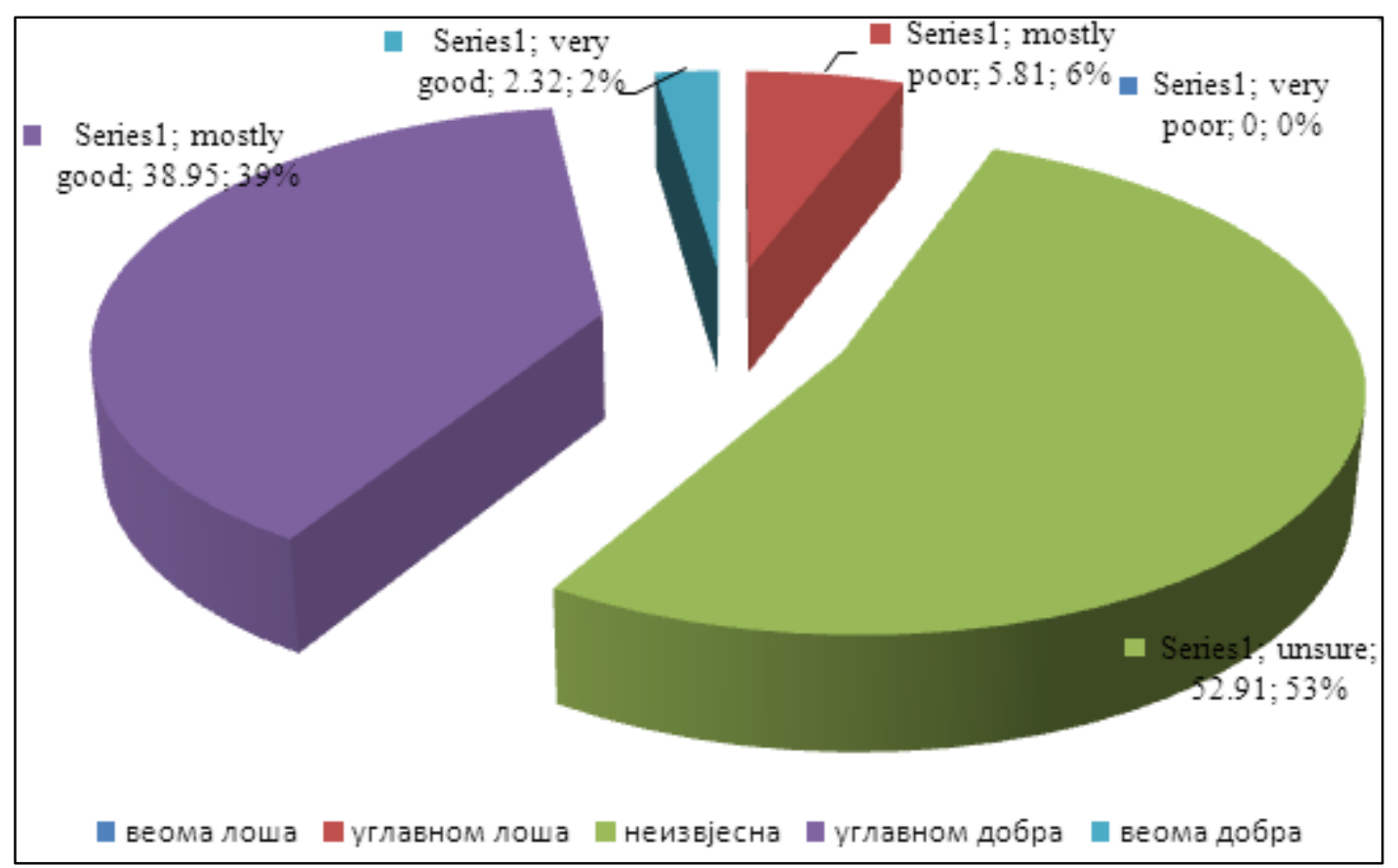

Figure 1. Distribution of the results for the vision of future - whole sample

Indicators of distribution of results for the surveyed students' vision of future give a precise picture of students toward the future, being presented in the following table and figure.

Table 6. Distribution of the results for the vision of future - whole sample

\begin{tabular}{|c|c|c|}
\hline Vision of the future intensity & $\mathrm{N}$ & $\%$ \\
\hline Very poor & 0 & 0,00 \\
\hline Mostly poor & 40 & 5.81 \\
\hline Unsure & 364 & 52.91 \\
\hline Mostly good & 268 & 38.95 \\
\hline Very good & 16 & 2.32 \\
\hline
\end{tabular}

However, it is obvious that none of surveyed students perceives his/her future as extremely pessimistic, i.e. very poor; $5.81 \%$ of the surveyed perceives the future as mostly poor; every other student or 52.91 perceives the future as unsure; $38.95 \%$ of students perceives the future as good while only $2.32 \%$ of them perceive it as very good. In that context, the obtained results of thoughts and views regarding the future of students suggest there are importantly more positive than negative expectations from the future, despite the difficult socio-economic situation in which young people live, taking into account the significantly emphasized result of number of respondents who have a vision of the future as unsure one. This is acceptable if we take into account difficult live situation of the majority of citizens as well as announcements of even more difficult and unsure days in the future. This result confirms our standpoint that all persons set goals to which they strive in their lives and according to which they adjust their activities in a real social environment, so young persons of high school age form their vision of the future in a real life environment.
In the analysis of issues important for perceiving similarities and differences in the vision of future among gifted and other students, there has been set a hypothesis "that differences in the perception of future between gifted and other students may be expected". The gifted have more specific activities in realizing their potentials so there is a possibility they perceive themselves differently and have different view toward the future.

Table 7. Vision of the future of gifted and other students

\begin{tabular}{|c|c|c|c|c|c|}
\hline \multirow{3}{*}{ Students } & \multicolumn{3}{|c|}{ PERCEPTION OF THE FUTURE } & \multirow{2}{*}{$\sum$} \\
\cline { 2 - 5 } & $\begin{array}{c}\text { mostly } \\
\text { poor }\end{array}$ & unsure & $\begin{array}{c}\text { mostly } \\
\text { good }\end{array}$ & $\begin{array}{c}\text { very } \\
\text { good }\end{array}$ & \\
\hline \multirow{3}{*}{ Gifted } & 18 & 110 & 84 & 4 & \multirow{2}{*}{216} \\
\cline { 2 - 5 } & 8.33 & 50.93 & 38.89 & 1.85 & \\
\hline \multirow{2}{*}{ Other } & 22 & 254 & 184 & 12 & \multirow{2}{*}{472} \\
\cline { 2 - 5 } & 4.66 & 53.81 & 38.98 & 2.54 & \\
\hline \multirow{2}{*}{ Total } & 40 & 364 & 268 & 16 & \multirow{2}{*}{688} \\
\cline { 2 - 5 } & 5.81 & 52.91 & 38.95 & 2.33 & \\
\hline
\end{tabular}

Pearson Chi-square: $3.97500, \mathrm{df}=3, \mathrm{p}=.26419$

Having an insight into the results presented in such a way, it is evident that no statistically significant differences have been found in the perception of future between gifted and other students, taking into account that the obtained Chi-square test is 3.97500 with 3 degrees of freedom and is not statistically significant at any of the levels for the common testing represents a difference between perceived distributions $(p=.264196)$. Therefore, distributed results of perception between gifted and other students indicate that the established distributions of the vision of future so similar, so there is no statistically significant differences in their thoughts and views toward the future. In such a way, a 
conclusion has been made that the set hypothesis is no longer acceptable, i.e. "that differences in the perception of future between gifted and other students may not be expected".

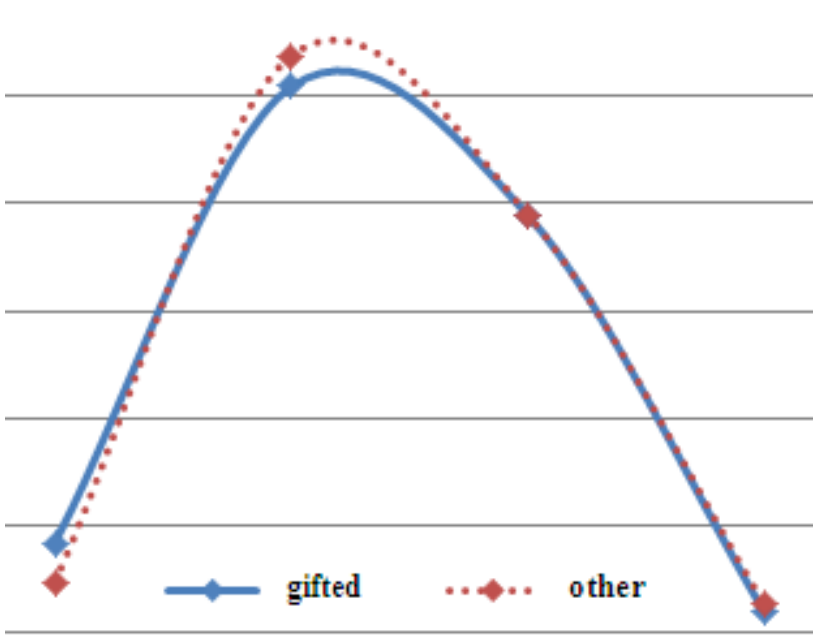

Figure 2. Vision of the future of gifted and other students

\section{Instead of the Conclusions}

Research of performance of gifted and other students is a significant field of research, whose results may contribute to better understanding of the natural performance and position of gifted individuals in the society, generally. It is well-known that many factors affect the school success of gifted and other students, a lot of research suggest that the school success is affected by the characteristics of a student, the organization of educational process and grading system, etc. In our research, characterized as a transversal research, conducted on a sample of 688 high school students (from music and art schools, grammar schools, technical and vocational schools in the Republic of Srpska, Bosnia and Herzegovina, we have showed only a part of the results, which more precisely point out the perception of present and the vision of future of both gifted and other students, as sources of differences in their school performance. In general, the performance of gifted is presented through their success in a previous class while self-awareness is being operationalized as the perception of present and the vision of future. The obtained results of researching the perception of present of students (the whole sample) show more positive than negative or neutral attitudes, despite difficult socio-economic situation in which young people live, supporting our standpoint that all persons set certain goals to themselves to which they strive and according to which they undertake activities in a real social environment. In the analysis of similarities and differences in the perception of the present of both gifted and other students, the obtained results indicate that there have been established some statistically significant differences (Chi-square $=9.55196$, $\mathrm{df}=3, \mathrm{p}=.022798$ ). It follows that gifted students have more pessimistic a picture of present, suggesting that the hypothesis "that differences in the perception of present between gifted and other students may be expected" shall be accepted. Regarding the issue of perceiving the vision of future, it is evident that there have not been established any statistically significant differences of the perception of future between gifted and other students (Chi-square $=3.97500$, $\mathrm{df}=3, \mathrm{p}=.264196$ ). Distributed results of the perception of future between gifted and other students (Figure 2.) show that established distributions of the vision of future are very similar, so there is no statistically significant differences in their thoughts and views toward the future. The research sample involved students from 15 to 18 years of age. It is $a$ multistage sample, appropriate with elements of random selection, so it may be regarded as adequate and representative for purposes of this research. It follows that obtained results, as well as conclusions made in accordance with them, are reliable, so general conclusions shall be considered scientifically objective. The obtained results of the research (make an intersection) of the time period in which it was conducted and may be used for perceiving more real self-awareness and school performance of both gifted and other students.

\section{REFERENCES}

[1] Andrilovic V, and Cudina M, Psihologija ucenja i nastave [Psychology of Learning and Teaching] Skolska knjiga, Zagreb, 1985.

[2] Djuric Dj, Vaspitanje mladih u visenacionalnoj zajednici [The Education of Youth in a Multinational Community], Pedagoski zavod Vojvodine, Novi Sad, 1987.

[3] Djordjevic B, and Djordjevic J, Ucenici o svojstvima nastavnika [Students about Their Teachers' Features]. Prosveta, Beograd, 1988.

[4] Gojkov G, Didaktika darovitih [Didacties of Gifted]: Visoka skola strukovnih studija za obrazovanje vaspitaca, Mihailo Pavlov, Vrsac, 2008.

[5] Havelka N, Efekti osnovnog skolovanja [Effects of Primary Education], Institut za psihologiju, Beograd, 1972.

[6] Havelka N, Uloga nastavnika i uloga ucenika u osnovnoj skoli [Role of a Teacher and a Student in Primary School]: Uciteljski fakulteti Srbije, Beograd, 1998.

[7] Krneta D, Perspektive razvoja mladih talenata u izmjenjenim ambijentalim uslovima [Prospects for the Development of Young Talent in the Changed Environmental Conditions]: VIII Okrugli sto ". Visa skola za obrazovanje vaspitaca, Vrsac-Temisvar, 2002.

[8] Krneta D, i Krneta Lj, Daroviti u ocima drugih [Gifted in the Eyes of Others], Zbornik 11 [133-147] Visa skola za obrazovanje vaspitaca, Vrsac-Temisvar, 2005.

[9] Krneta D, Odabrana poglavlja iz edukacijske psihologije[Selected Chapters of Educational Psychology], TT Centar, Banja Luka, 2004. 
[10] Krneta Lj, Faktori skolskog uspjeha [Factors of School Performance], Banja Luka Company, Banja Luka, 2000.

[11] Krneta $\mathrm{Lj}$, Licnost ucenika i percepcija radne efikasnosti nastavnika [Personality of Students and Perception of Working Efficiency of Teachers], Grafid, Banja Luka, 2010.

[12] Krneta Lj, i Simunic E, Podsticanje emocionalne kompetentnosti darovitih ucenika u skoli [Developing Emotional Competence in Gifted Students at the School], Visoka skola strukovnih studija za obrazovanje vaspitacaMihailo Pavlov, Zbornik 18 [200-215], Vrsac-Temisvar , 2013.

[13] Kvascev R, Podsticanje i razvijanje stvaralackog ponasanja licnosti [Fostering and Developing the Creative Behavior of Personality], Svjetlost, Sarajevo, 1975.

[14] Kvascev R, i Radovanovic V, Uticaj sposobnosti, slozaja licnosti i motivacije na uspjeh u skolskom ucenju [The Impact of Capacity, Complexity of Personality and Motivation to Succeed in School Learning] Psihologija 1: 5-20, Beograd, 1977.

[15] Litvinovic G, Covek izmedju istorijskog i licnog vremena [A Human Being between Historical and Personal Time]: Institut za psihologiju, Beograd, 2001.

[16] Roth N, and Havelka N, Nacionalna vezanost i vrednosti srednjoskolske omladine [National Ties and Values in High School Students]: Institut za drustvena istrazivanja, Beograd, 1973.

[17] Roth N, and Havelka N, Izrada skale za ispitivanje oblika nacionalne vezanosti [Constructing of Scale for Testing Forms of National Attachment], IV kongres psihologa Jugoslavije, Ljubljana, 1972. 